\title{
Peningkatan Kompetensi Psikomotor Siswa Melalui Model Pembelajaran Project Based Learning (PjBL) di SMKN 5 Padang : PDS Project
}

\author{
Fivia Eliza $^{1}$, Suriyadi ${ }^{2}$ dan Doni Tri Putra Yanto ${ }^{1}$ \\ ${ }^{1}$ Jurusan Teknik Elektro, Fakultas Teknik, Universitas Negeri Padang \\ ${ }^{2}$ SMK Negeri 5 Padang \\ *Corresponding author, e-mail: fivia_eliza@ft.unp.ac.id
}

\begin{abstract}
Abstrak - PDS adalah kegiatan Revitalisasi LPTK yang mengharuskan dosen mengalami langsung bagaimana menjadi guru. SMKN 5 Padang merupakan salah satu Sekolah Menengah Kejuruan bidang teknologi yang memiliki bidang keahlian teknologi Teknik Instlasi Tenaga Listrik, tujuan program keahlian ini adalah menghasilkan lulusan yang berkompeten secara teoritis dan praktis dalam bidang Instalasi Tenaga Listrik. Untuk mencapai hal tersebut proses pembelajaran Instalasi Motor Listrik tidak bisa dilakukan hanya dengan model pembelajaran konvensional yaitu metode ceramah dan tanya jawab untuk penyampaian materi kemudian dilanjutkan dengan siswa melaksanakan praktikum berdasarkan gambar dan petunjuk yang diberikan oleh guru selama penyampaian materi pembelajaran. Untuk itu dilakukan penelitian tindakan kelas (action research) yang bertujuan untuk meningkatkan kompetensi psikomotor siswa dengan penerapan model pembelajaran Project Based Learning $(\mathrm{PjBL})$ pada proses pembelajaran Instalasi Motor Listrik di kelas XI. Hasil penelitian ini menunjukkan bahwa pada ranah psikomotor siklus 1 telah terjadi peningkatan hasil belajar siswa jika dibandingkan dengan hasil belajar dengan model pembelajaran yang sebelumnya. Kemudian peningkatan hasil belajar siswa semakin membaik pada siklus 2 setelah dilakukan beberapa penyempurnaan dalam pelaksanaanya. Dengan demikian dapat disimpulkan bahwa model pembelajaran Project Based Learning dapat meningkatkan kompetensi psikomotor siswa pada proses pembelajaran Instalasi Motor Listrik.
\end{abstract}

Kata Kunci : Kata kunci satu, Kata kunci dua dan Kata kunci tiga, Maksimal Lima

\begin{abstract}
PDS is an LPTK Revitalization activity that requires lecturers to experience firsthand how to become a teacher. SMKN 5 Padang is one of the Vocational Schools which has the field of electric power engineering technology expertise, that aimed to produce graduates who are theoretically and practically competent in the field of electric power installation. To achieve this, the learning process of the Electric Motor Installation cannot be done only with conventional learning models, namely the lecture and question and answer method for the delivery of material and then proceed with the students carrying out the practice based on the images and instructions given by the teacher during the learning process. For this reason, class action research (action research) is conducted which aims to improve students' psychomotor competences by applying Project Based Learning (PjBL) learning models in the learning process of Electric Motor Installation in students class XI. The results of this study indicate that in the psychomotor domain of cycle 1 there has been an increase in student learning outcomes when compared with learning outcomes with the previous learning model. Then the improvement of student learning outcomes is getting better in cycle 2 after some improvements have been made in the implementation. Thus it can be concluded that the Project Based Learning learning model can improve students' psychomotor competence in the learning process of Electric Motor Installation.
\end{abstract}

Keywords : Project Based Learning, PTK, Electric Motor Installation, Vocational School

This is an open access article distributed under the Creative Commons 4.0 Attribution License 


\section{Pendahuluan}

Untuk mewujudkan negara Indonesia yang maju, modern, demokratis, dan berkeadilan diperlukan sumber daya manusia yang unggul dan berkarakter yang hanya dapat dihasilkan dari pendidikan yang unggul dengan guru-guru yang unggul, dan guru-guru yang unggul hanya dihasilkan melalui pendidikan guru (LPTK) yang unggul di LPTK yang unggul. Unsur utama pendidikan guru adalah dosen. Di samping harus memiliki kompetensi yang unggul, dosen LPTK juga harus menjadi model bagi mahasiswa calon guru. Oleh karenanya, dosen harus mampu memberikan contoh baik bagi mahasiswa calon guru, dalam melaksanakan tugas keprofesiannya, termasuk bagaimana melaksanakan pembelajaran di kelas. Agar dosen LPTK pada saat melaksanakan tugas pembelajaran mampu menghadirkan pengalaman nyata bagaimana melaksanakan pembelajaran yang baik, yang relevan dengan tuntutan mutu proses pembelajaran di sekolah, maka dosen harus mengalami langsung bagaimana menjadi guru melalui suatu program penugasan dosen di sekolah (PDS).

PDS merupakan kegiatan yang memberikan dampak positif baik bagi LPTK maupun bagi Sekolah Laboratorium dan/atau Sekolah Mitra. Program PDS membutuhkan komitmen dosen untuk mengalami dan menjadi guru di Sekolah Laboratorium dan/atau Sekolah Mitra. Menjadi guru di sekolah bagi seorang dosen adalah hal baru. Dosen perlu menyesuaikan dengan berbagai hal yang biasa berlaku di sekolah. Penugasan dosen di sekolah juga dapat memunculkan permasalahan baru bagi Sekolah Laboratorium dan/atau Sekolah Mitra, yaitu apakah dosen yang bertugas dapat menyesuaikan dengan lingkungan yang sangat berbeda dengan tempat tugasnya di perguruan tinggi.

Berdasarkan penugasan dosen di SMKN 5 Padang, dua minggu pertama adalah observasi. Hasil observasi awal yang dilakukan pada proses pembelajaran Instalasi Mesin Listrik siswa Kelas XI Teknik Instalasi Tenaga Listrik di SMKN 5 Padang, proses pembelajaran dilakukan dengan model pembelajaran konvensional yaitu metode ceramah dan tanya jawab untuk penyampaian materi kemudian dilanjutkan dengan siswa melaksanakan praktikum berdasarkan gambar dan petunjuk yang diberikan oleh guru selama penyampaian materi pembelajaran. Proses pembelajaran dengan menggunakan metode ini terlihat tidak efektif, hal ini dindikasikan dengan banyak siswa yang kebingungan dalam melaksanakan praktikum karena kesulitan memahami materi yang disampaikan oleh guru melalui metode ceramah. Hal ini diperkuat dengan tes kompetensi psikomotor tentang prinsip kerja rangkaian dan tata letak komponen instalasi motor pada pertemuan ke 3, bahwa siswa masih banyak yang belum paham dan tidak bisa menjawab pertanyaan lisan yang diberikan guru. Kemudian mengingat sifat dari mata pelajaran ini adalah gabungan antara teori dan praktek serta bertujuan meningkatkan kompetensi keahlian siswa dalam memahami dan memasang sistem kendali motor listrik baik secara manual maupun semiotomatis, maka dibutuhkan sebuah model yang mampu mengakomodasi dan mendukung tujuan dari proses pembelajaran bidang psikomotor tersebut.

Berdasarkan karakteristik mata pelajaran dan analisis siswa maka model pembelajaran project based learning (PjBL) cocok sebagai model pembelajaran yang akan diterapakan pada proses pembelajaran instalasi motor listrik ini. ProjectBased Learning (PjBL) adalah model pembelajaran yang menggunakan proyek/ kegiatan sebagai proses pembelajaran untuk mencapai kompentensi sikap, pengetahuan dan keterampilan. Project Based Learning merupakan pembelajaran inovatif yang berpusat pada siswa (student centered) dan menempatkan pendidik sebagai motivator dan fasilitator, dimana siswa diberi peluang bekerja secara otonom mengkonstruksi belajarnya.[1]

Dari uraian tersebut maka perlu dilakukan penelitian tentang penerapan Model Pembelajaran Project based Learning (PjBL) dalam upaya meningkatkan kompetensi keahlian siswa. Penelitian ini bertujuan untuk peningkatan kompetensi psikomotor siswa setelah penerapan model pembelajaran Project Based Learning (PjBL) dalam pembelajaran Instalasi Motor Listrik di kelas XI Teknik Instalasi Tenaga Listrik di SMKN 5 Padang.

\section{A. Model dan Metode Pembelajaran}

Model pembelajaran ialah cara yang dipergunakan pendidik dalam mengadakan hubungan dengan siswa pada saat berlangsungnya pengajaran.[2] Sedangkan Metode pembelajaran adalah cara-cara menyajikan materi pelajaran yang dilakukan oleh pendidik agar terjadi proses pembelajaran pada diri siswa dalam upaya untuk mencapai tujuan.[3] Pendidik harus mempertimbangkan model pembelajaran yang akan digunakan dalam proses pembelajaran, ada tiga aspek yang perlu dipertimbangkan pendidik dalam memilih model pembelajaran yaitu hasil, isi 
materi, dan proses pembelajaran itu sendiri. [4] Model pembelajaran yang paling banyak diterapkan oleh pendidik pada waktu dulu adalah metode ceramah atau lebih dikenal dengan metode konvensional.[5] Namun seiring dengan perkembangan zaman para pakar pendidikan berhasil menemukan berbagai macam model pembelajaran yang kreatif dan inovarif. Pendidik saat ini bisa memilih dan menerapkan model pembelajaran yang sesuai sehingga mampu mencapai tujuan dari pelaksanaan pembelajaran.

Model pembelajaran yang diterapkan di SMKN 5 Padang sebelum penerapan model pembelajaran berbasis proyek adalah menggunakan Jobsheet. Jobsheet merupakan lembaran-lembaran yang berisi tugas yang harus dikerjakan oleh siswa. Format penulisan jobsheet meliputi: judul, petunjuk belajar, kompetensi dasar/ mata pelajaran, langkah kerja/ tugas, dan penilaian. [5] Berdasarkan pengertian dan format penulisan jobsheet dapat disimpulkan bahwa pembelajaran yang mengunakan jobsheet memberikan kemudahan kepada siswa untuk melaksanakan pratikum karena di dalam jobsheet sudah jelas prosedur/ langkah kerja selama pratikum. Namun hal ini memberikan batasan kepada siswa untuk mengasah kreativitas selama melaksanakan pratikum.

\section{B. Pembelajaran Berbasis Proyek}

Pembelajaran berbasis proyek (Project Based Learning $=P j B L)$ adalah metode pembelajaran yang menggunakan proyek/kegiatan sebagai media.[6] Siswa melakukan eksplorasi, penilaian, interpretasi, sintesis, dan informasi untuk menghasilkan berbagai bentuk hasil belajar. Project based learning/Pembelajaran Berbasis Proyek merupakan metode pembelajaran yang memberikan kesempatan kepada tenaga pendidik untuk mengelola pembelajaran di kelas dengan melibatkan kerja proyek. Kerja proyek memuat tugas-tugas yang kompleks berdasarkan kepada pertanyaan dan permasalahan (problem) yang sangat menantang, dan menuntut siswa untuk merancang, memecahkan masalah, membuat keputusan, melakukan kegiatan investigasi, serta memberikan kesempatan kepada siswa untuk bekerja secara mandiri. Tujuannya adalah agar siswa mempunyai kemandirian dalam menyelesaikan tugas yang dihadapinya.[7]

Project Based Learning is a teaching method in which students gain knowledge and skills by working for an extended period of time to investigate and respond to a complex question, problem, or challenge. [8]
Project-based Learning (PBL) is a model for classroom activity that shifts away from the usual classroom practices of short, isolated, teachercentred lessons. PBL learning activities are long-term, interdisciplinary, student-centred, and integrated with real-world issues and practices.[8]

Berdasarkan dari beberapa pendapat ahli tentang pengertian Project Based Learning disimpulkan bahwa Project Based Learning merupakan suatu metode pembelajaran inovatif yang berpusat pada siswa (student centered) dan menempatkan tenaga pendidik sebagai motivator dan fasilitator, siswa diberi kesempatan untuk bekerja secara otonom dalam mengkonstruksi belajarnya. Metode ini memiliki kecocokan terhadap konsep inovasi pendidikan bidang keteknikan, terutama dalam hal sebagai berikut (1) pelajar memperoleh pengetahuan dasar (basic sciences) yang berguna untuk memecahkan masalah bidang keteknikan yang dijumpainya, (2) pelajar belajar secara aktif dan mandiri dengan sajian materi terintegrasi dan relevan dengan kenyataan sebenarnya, yang sering disebut studentcentered, (3) pelajar mampu berpikir kritis, dan mengembangkan inisiatif.

Pembelajaran Berbasis Proyek merupakan metode belajar yang menggunakan masalah sebagai langkah awal dalam mengumpulkan dan mengintegrasikan pengetahuan baru berdasarkan pengalamannya dalam beraktifitas secara nyata. Pembelajaran berbasis proyek dirancang untuk digunakan pada permasalahan komplek yang diperlukan siswa dalam melakukan insvestigasi dan memahaminya. Melalui $P j B L$, proses inquiry dimulai dengan memunculkan pertanyaan penuntun (a $\quad$ guiding question) dan membimbing siswa dalam sebuah proyek kolaboratif yang mengintegrasikan berbagai subjek (materi) dalam kurikulum. Pada saat pertanyaan terjawab, secara langsung siswa dapat melihat berbagai elemen utama sekaligus berbagai prinsip dalam sebuah disiplin yang sedang dikajinya. $P j B L$ merupakan investigasi mendalam tentang sebuah topik dunia nyata, hal ini akan berharga bagi atensi dan usaha siswa.

Mengingat bahwa masing-masing siswa memiliki gaya belajar yang berbeda, maka pembelajaran berbasis proyek memberikan kesempatan kepada para siswa untuk menggali konten (materi) dengan menggunakan berbagai cara yang bermakna bagi dirinya, dan melakukan eksperimen secara kolaboratif.[9]

C. Tujuan Model Pembelajaran Project Based Learning 
1) Meningkatkan kemampuan siswa dalam pemecahan masalah proyek.

2) Memperoleh pengetahuan dan keterampilan baru dalam pembelajaran

3) Membuat siswa lebih aktif dalam memecahkan masalah proyek yang kompleks dengan hasil produk nyata.

4) Mengembangkan dan meningkatkan keterampilan siswa dalam mengelola bahan atau alat untuk menyelesaikan tugas atau proyek.

5) Meningkatkan kolaborasi siswa khususnya pada PjBL yang bersifat kelompok.

\section{Ciri-Ciri Model Pembelajaran Project Based} Learning

1) Isi, difokuskan pada ide-ide siswa yaitu dalam membentuk gambaran sendiri bekerja atas topik-topik yang relevan dan minat siswa yang seimbang dengan pengalaman mereka seharihari.

2) Kondisi, untuk mendorong siswa belajar secara mandiri, yaitu dalam mengelola tugas dan waktu belajar sehingga dalam belajar Praktik siswa mencari sumber informasi secara mandiri dari berbagai referensi seperti buku maupun internet.

3) Aktivitas, yaitu kegiatan yang efektif dan menarik, yaitu dalam mencari jawaban atas pertanyaan-pertanyaan dan memecahkan masalah-masalah menggunakan kecakapan. Aktivitas juga merupakan bangunan dalam menggagas pengetahuan siswa dalam mentransfer dan menyimpan informasi dengan mudah. Pada saat proses pembelajaran siswa dituntut untuk aktif, menggunakan kecakapan untuk memecahkan masalah dan berbagai tujuan belajar yang ingin dicapai.

4) Hasil, yaitu penerapan hasil yang produktif dalam membantu siswa mengembangkan kecakapan belajar dan mengintegrasikan dalam belajar yang sempurna, termasuk strategi dan kemampuan untuk mempergunakan kognitif strategi pemecahan masalah. Juga termasuk kecakapan tertentu, disposisi, sikap dan kepercayaan yang dihubungkan dengan pekerjaan produktif, sehingga secara efektif dapat menyempurnakan tujuan yang sulit untuk dicapai dengan model-model pengajaran yang lain.[10]

\section{Metode Penelitian}

Penelitian ini dilaksanakan di SMKN 5 Padang jurusan Teknik Instalasi Tenaga Listrik (TITL). Waktu pelaksanaan penelitian dilaksanakan pada semester Juli-Desember 2018 sesuai dengan kalender akademik yang telah ditetapkan oleh Dinas Pendidikan Provinsi Sumatera Barat.

Subjek dalam penelitian ini siswa kelas XI Jurusan Teknik Instalasi Tenaga Listrik di SMKN 5 padang yang tergabung pada proses pembelajaran Instalasi Motor Listrik yang berjumlah 16 orang. Penelitian ini menerapkan model pembelajaran Project Based Learning (PjBL) yang bertujuan untuk meningkatkan kreativitas dan kompetensi keahlian siswa.

Metode penelitian yang digunakan untuk melihat ketercapaian dari penerapan model pembelajaran ini adalah Penelitian Tindakan Kelas (Classroom Action Research). Penelitian Tindakan Kelas merupakan suatu pencermatan terhadap kegiatan belajar yang berbentuk sebuah tindakan, yang sengaja dimunculkan dan terjadi dalam sebuah kelas secara bersama.[11]

Prosedur kerja dalam penelitian tindakan kelas terdiri atas empat komponen, yaitu perencanaan (planning), tindakan (acting), pengamatan (observing), dan refleksi (reflecting), yang keempatnya merupakan satu siklus.[12]

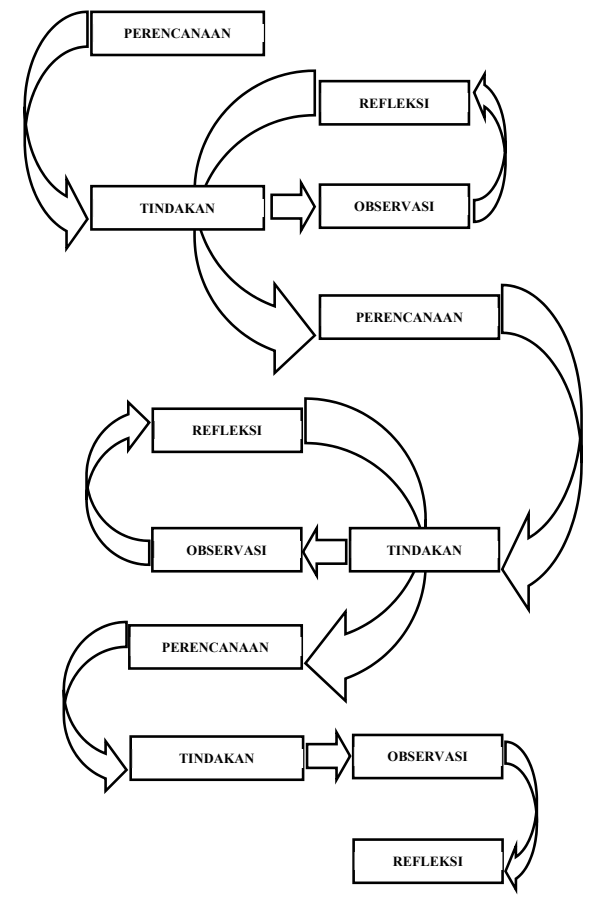

Gambar 1. Siklus PTK Model Kemmis dan McTaggart 
Instrumen yang digunakan untuk pengumpulan data pada penelitian ini adalah instrumen penilaian hasil belajar siswa berupa rubrik penilaian kinerja. Rubrik penilaian kinerja merupakan instrumen yang digunakan untuk mengukur kinerja siswa pada saat pelaksanaan proses pembelajaran praktikum, dimana aspek yang dinilai berada pada ranah psikomotorik, rubrik ini digunakan untuk mengumpulan data kinerja siswa pada saat proses praktikum untuk mendukung hasil belajar ranah kognitif siswa yang didapatkan dari instrumen soal objektif. Rubrik penilaian kinerja ini dinilai dan diisi oleh guru (observer) pada saat proses pembelajaran praktikum atau pelaksanaan dan eksekusi proyek pada model pembelajaran berbasisi proyek. [13]

Rubrik penilaian kinerja ini sebelum digunakan telah divalidasi oleh ahli yang bertujuan agar rubrik penilaian kinerja benar-benar cocok dan mampu mengukur kinerja siswa selama proses pembelajaran praktikum pada proses pembelajaran instalasi motor listrik. validasi dilakukan oleh dua orang ahli instrumen dan evaluasi pembelajaran di jurusan Teknik Elektro Fakultas Teknik Universitas Negeri Padang. Format rubrik penilaian kinerja :

\section{RUBRIK PENILAIAN KINERJA}

Nama Siswa

Program Studi

Judul Jobsheet

\begin{tabular}{|c|c|c|c|c|c|c|c|}
\hline \multirow{2}{*}{$\begin{array}{l}\mathbf{N} \\
\mathbf{0}\end{array}$} & \multirow[t]{2}{*}{ Kinerja } & \multicolumn{5}{|c|}{ Penilaian } & \multirow[t]{2}{*}{ Ket. } \\
\hline & & $\mathbf{0}$ & 1 & 2 & 3 & 4 & \\
\hline & $\begin{array}{l}\text { PERSIAPAN } \\
\text { PRAKTIKUM }\end{array}$ & & & & & & \\
\hline \begin{tabular}{l|l}
1 & \\
\end{tabular} & $\begin{array}{l}\text { Membawa perlengkapan } \\
\text { proyek praktikum (alat/bahan } \\
\text { yang ditugaskan) }\end{array}$ & & & & & & \\
\hline 2 & $\begin{array}{l}\text { Memakai baju proyek } \\
\text { praktikum dan berpenampilan } \\
\text { rapi }\end{array}$ & & & & & & \\
\hline & $\begin{array}{l}\text { SELAMA KEGIATAN } \\
\text { PROYEK PRAKTIKUM }\end{array}$ & & & & & & \\
\hline & $\begin{array}{l}\text { A. Menggunakan Alat dan } \\
\text { Bahan }\end{array}$ & & & & & & \\
\hline 1 & $\begin{array}{l}\text { Mengambil bahan dengan rapi } \\
\text { tidak berceceran }\end{array}$ & & & & & & \\
\hline 2 & $\begin{array}{l}\text { Mengambil bahan proyek } \\
\text { praktikum sesuai kebutuhan }\end{array}$ & & & & & & \\
\hline 3 & $\begin{array}{l}\text { Memaknai dan Menelaah } \\
\text { Gambar rangkaian Proyek } \\
\text { praktikum dengan benar }\end{array}$ & & & & & & \\
\hline 4 & $\begin{array}{l}\text { Mengoperasikan alat dengan } \\
\text { benar }\end{array}$ & & & & & & \\
\hline 5 & $\begin{array}{l}\text { Menggunakan alat dan bahan } \\
\text { sesuai prosedur proyek } \\
\text { praktikum }\end{array}$ & & & & & & \\
\hline & $\begin{array}{l}\text { B. Kemauan, keterampilan } \\
\text { mengamati menganalisis } \\
\text { dan menyimpulkan hasil } \\
\text { proyek praktikum }\end{array}$ & & & & & & \\
\hline
\end{tabular}

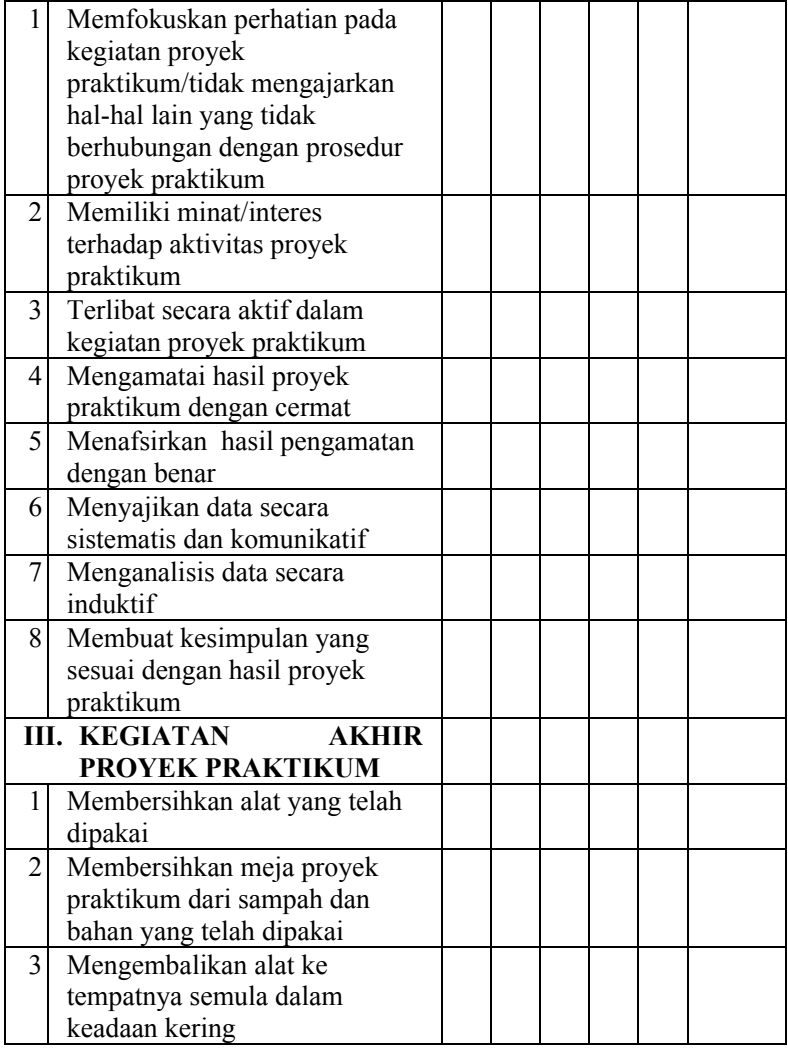

\section{Teknik Analisis Data}

Teknik analisis data yang digunakan adalah memenuhi langkah-langkah berikut:[13] [14]

a. Skor Jawaban dengan kriteria sebagai berikut :

$$
\begin{array}{ll}
1 & =\text { Istimewa } \\
2 & =\text { Baik } \\
3 & =\text { Cukup } \\
4 & =\text { Kurang } \\
5 & =\text { Sangat Kurang }
\end{array}
$$

b. Menentukan skor rata-rata yang didapat dengan cara menjumlahkan nilai yang didapat dari banyak indikator

c. Skor maksimum pada masing-masing item rubtrik nilainya adalah 5

d. Pemberian nilai kinerja dengan rumus :

Nilai kinerja dalam $\%=\frac{\text { Nilai kinerja total }}{\text { Nilai kinerja maksimum }} X 100 \%$

e. Memberikan penilaian terhadap kinerja dan produk siswa dengan kriteria disajikan pada tabel

Tabel 3.10. Klasifikasi Kinerja dan Produk Siswa

\begin{tabular}{|c|c|c|}
\hline No. & $\begin{array}{c}\text { Tingkat } \\
\text { Pencapaian (\%) }\end{array}$ & Klasifikasi \\
\hline 1 & $81-100$ & Istimewa \\
\hline 2 & $61-80$ & Baik \\
\hline 3 & $41-60$ & Cukup \\
\hline 4 & $21-40$ & Kurang \\
\hline 5 & $0-20$ & Sangat Kurang \\
\hline
\end{tabular}




\section{HASIL DAN PEMBAHASAN}

\section{A. Siklus 1}

\section{a. Perencanaan}

Sebelum melakukan tindakan pada penelitian ini maka peneliti terlebih dahulu mempersiapkan segala sesuatu yang diperlukan dalam penelitian, yang meliputi bahan ajar, Rencana Pelaksanaan Pembelajaran, dan silabus yang telah disesuaikan dengan rencana tindakan. Selanjutnya peneliti mempersiapkan instrument yang akan digunakan dalam penelitian. pengukuran hasil belajar siswa dan lembar rubric penilaian kinerja dan produk yang dihasikan oleh siswa.

\section{b. Tindakan}

Pelaksanaan tindakan yang dilakukan pada siklus 1 adalah 2 kali pertemuan, dimana selama 2 kali pertemuan tersebut terdiri dari sepuluh fase atau tahapan model pembelajaran project based learning.

\section{1) Pertemuan Pertama}

Proses pembelajaran diawali dengan guru membaca salam sebagai tanda pembelajaran dimulai. Guru mengkondisikan kelas dengan mencek kehadiran siswa. Pembelajaran dilanjutkan dengan guru memberikan motivasi kepada siswa melalui cara menjelaskan aplikasi Instalasi motor listrik di dunia industri dan dunia usaha.

Pembelajaran dengan menerapkan model pembelajaran project based learning dimulai dengan guru menyampaikan kepada siswa tentang capaian pembelajaran dan menjelaskan tujuan dari penerapan tugas kerja yang berbentuk proyek. Guru menjelaskan kepada siswa tentang tahapan proses dari model pembelajaran berbasis proyek. Guru membagi siswa ke dalam kelompok dimana satu kelompok terdiri dari 4 orang. Setelah siswa menempatkan diri pada kelompok masing-masing maka terlebih dahulu guru menjelaskan tentang bentuk proyek yang akan dikerjakan oleh siswa, dimana bentuk proyek yang akan dikerjakan harus berhubungan dengan materi ajar.Guru memberikan tugas kepada masing-masing kelompok untuk merancang proyek yang akan dibuat, selama proses perancangan proyek berlangsung guru memiliki peran sebagai pendamping serta memonitoring dan melayani konsultasi pembuatan rancangan proyek dari kelompok. Pada siklus 1 ini guru harus lebih sering untuk memotivasi siswa agar lebih kreatif dalam merancang bentuk proyek yang akan dikerjakan.

Guru memeriksa hasil rancangan tiap-tiap kelompok dan memberikan masukan bagi rancangan yang belum mencakup unsur dari materi yang telah diajarkan. Kemudia hasil perencanaan dipresentasikan dan didiskusikan dengan kelompok lain. Saran dan masukan dari kelompok lain dijadikan acuan dalam perbaikan proyek yang direncanakan

\section{2) Pertemuan Kedua}

Pertemuan kedua sama halnya dengan tindakan yang dilakukan pada pertemuan pertama, guru mengkondisikan kelas dengan mencek kehadiran siswa. Pembelajaran dilanjutkan dengan guru memberikan motivasi kepada siswa melalui cara menjelaskan aplikasi materi pembelajaran Instalasi motor listrik di dunia industri dan dunia usaha.

Kelompok melapor ke teknisi agar dapat mempersiapkan peralatan dan bahan yang dibutuhkan untuk pembuatan proyek, setelah alat dan bahan dipersiapkan maka kelompok memulai proses pembuatan sesuai dengan rancangan yang telah disetujui oleh guru pengampu mata kuliah Instalasi motor listrik.

Siswa melaksanakan proses pembuatan proyek mulai dari pemotongan bahan, selama proses pembuatan proyek guru bertugas mendampingi dan membimbing siswa dalam melaksanakan praktik, serta menilai dan mengamati setiap langkah kerja yang dilakukan oleh setiap kelompok. Setelah selesai melaksanakan pratikum di pertemuan kedua ini maka siswa diintruksikan untuk mengembalikan peralatan dan membersihkan workshop.

Sebelum proses pratikum dibubarkan siswa dikumpulkan untuk menyampaikan kendala yang dihadapi selama proses pratikum sehingga ini menjadi bahan masukan untuk melakukan pratikum di pertemuan berikutnya. Pada akhir pertemuan dilakukan tes untuk mengukur hasil belajar siswa Selanjutnya guru menutup pembelajaran dan diakhiri salam.

c. Observasi

Observer selama penelitian melakukan pengamatan terhadap proses pembuatan proyek. Observer mengamati setiap kegiatan yang dilakukan oleh siswa untuk pengambilan data tentang proses pembuatan proyek. Pengamatan dilakukan selama proses pratikum berlangsung disetiap pertemuan pada siklus 1. Observer mengamati setiap kegiatan yang dilakukan kelompok dalam pembuatan proyek dan memberi tanda ceklist pada lembaran proyek sesuai dengan indikator yang ada pada lembaran proyek. Observer juga ikut dalam melakukan pengawasan terhadap kegiatan ujian yang dilakukan pada siklus 1.

Setelah dilakukan ujian pada siklus 1 maka peneliti melakukan penilaian. Hasil rubrik 
penilaian kinerja, dan tes pada siklus 1 diperoleh hasil sebagai berikut:

Kemampuan psikomotorik siswa didapatkan melalui hasil penilaian rubrik penilaian kinerja, yang disi selama siswa melakukan kegiatan pembelajaran praktikum, penilaian dilakukan oleh guru dan dosen dalam pelaksanaan proses pembelajaran. hasil rubrik penilaian kinerja disajikan pada tabel 4.1 berikut ini

Tabel 4.1. Hasil Belajar kemampuan Psikomotorik Siklus 1

\begin{tabular}{|c|c|c|c|}
\hline No & Responden & Nilai Total (\%) & Kriteria \\
\hline 1 & A & 82 & Sangat Baik \\
\hline 2 & B & 70 & Baik \\
\hline 3 & C & 75 & Baik \\
\hline 4 & D & 55 & Cukup \\
\hline 5 & E & 58 & Cukup \\
\hline 6 & F & 73 & Baik \\
\hline 7 & G & 65 & Baik \\
\hline 8 & H & 55 & Cukup \\
\hline 9 & I & 85 & Sangat Baik \\
\hline 10 & J & 78 & Baik \\
\hline 11 & K & 57 & Baik \\
\hline 12 & L & 85 & Sangat Baik \\
\hline 13 & M & 60 & Cukup \\
\hline 14 & N & 60 & Cukup \\
\hline 15 & O & 78 & Baik \\
\hline 16 & P & 80 & Baik \\
\hline \multicolumn{2}{|c|}{ Rata-Rata } & 69,75 & Baik \\
\hline
\end{tabular}

Dari tabel tersebut dapat diketahui bahwa masih terdapat 5 orang siswa belum mencapai nilai yang baik dimana masih berada pada taraf cukup, kemudian hanya 3 orang siswa yang memperoleh hasil belajar psikomotorik taraf maksimal (seperti terlihat pada gambar 4.1), namun jika dibandingkan dengan proses pembelajaran sebelumnya telah terdapat peningkatan pada beberapa siswa.

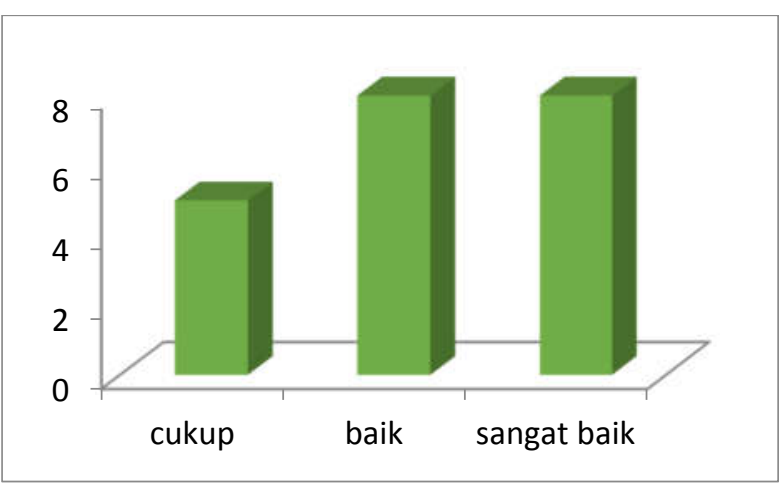

Gambar 4.1 Grafik Hasil Belajar Psikomotorik Siswa Siklus 1

\section{d. Refleksi}

Kegiatan yang dilakukan pada tahap refleksi ini adalah mendiskusikan hasil temuan yang diperoleh selama siklus 1 , dimana temuan tersebut dijadikan bahan pertimbangan untuk siklus selanjutnya. temuan-temuan tersebut adalah :

1) Pembelajaran yang telah dilaksanakan sudah mencerminkan penerapan model pembelajaran project based learning karena secara umum proses pembelajaran berjalan sesuai dengan rencana yang telah disusun.

2) Hasil belajar siswa yang mencapai KKM secara klasikal telah mengalami peningkatan jika dibandingkan dengan hasil belajar kognitif pada proses sebelumnya, namun KKM siswa secara klasikal belum mencapai $75 \%$ dari persyaratan ketuntasan dari sebuah proses pembelajaran.

3) Kemampuan psikomotor siswa juga mengalami peningkatan, 5 orang siswa memperoleh nilai cukup, delapan orang siswa memperoleh nilai baik, dan 3 lainnya telah mencapai nilai maksimal yakni pada taraf sangat baik.

4) Penerapan model pembelajaran berbasis proyek pada siklus 1 ini siswa masih bingung dan mengalami kendala dalam pembuatan proyek, karena ini baru pertama kali bagi siswa dalam mata kuliah praktik langsung membuat benda atau produk.

5) Siswa yang tidak mencapai kelulusan pada siklus 1 disebabkan karena sering tidak hadir sehingga hal ini berdampak kepada hasil kompetensi keahlian siswa itu sendiri.

Berdasarkan hasil siklus 1 maka pelaksanaaan siklus 2 diharapkan dapat berjalan dengan baik dengan memperhatikan tindakan-tindakan sebagai berikut:

1) Untuk meningkatkan hasil belajar dan kinerja siswa dalam proses pembelajaran pada siklus II, maka diambil tindakan-tindakan dengan 
merubah susunan kelompok dan memasukkan kelompok yang tidak aktif kepada kelompok yang aktif supaya terjadi interaksi kelompok dalam proses pembuatan proyek.

2) Melatih siswa untuk dapat berani mengeluarkan pendapat dan lebih aktif selama proses pembuatan proyek.

3) Meningkatkan kerjasama dalam kerja kelompok untuk melakukan penyelesaian pembuatan proyek.

\section{B. Siklus 2}

Berdasarkan refleksi pada siklus 1 maka dilakukan perbaikan-perbaikan terhadap pembelajaran pada siklus 2 yang tujuannya adalah agar terjadinya peningkatan pada siklus 2 . Proses tindakan yang dilakukan terdiri dari perencanaan, tindakan, observasi dan refleksi :

\section{a. Perencanaan}

Pada siklus 2 sebelum dilakukan tindakan penelitian maka terlebih dahulu peneliti mempersiapkan Modul Pembelajaran Instalasi motor listrik, RPP dan Silabus yang telah disesuaikan dengan rencana tindakan pada siklus 2 . Selanjutnya peneliti mempersiapkan instrument yang akan digunakan dalam penelitian yaitu berupa rubrik penilaian kinerja dan produk yang dihasilkan oleh siswa untuk tes siklus 2 .

\section{b. Tindakan}

\section{1) Pertemuan Pertama}

Proses pembelajaran diawali dengan guru membaca salam sebagai tanda pembelajaran dimulai. Guru mengkondisikan kelas dengan mengecek kehadiran siswa. Pembelajaran dilanjutkan dengan guru memberikan motivasi kepada siswa dengan cara menjelaskan materi pembelajaran Instalasi motor listrik.

Pembelajaran dengan menerapkan model pembelajaran project based learning dimulai dengan guru menyampaikan kepada siswa tentang capaian pembelajaran dan menjelaskan tujuan dari penerapan tugas kerja yang berbentuk proyek. Guru menjelaskan kepada siswa tentang tahapan proses dari model pembelajaran berbasis proyek. Guru membagi siswa ke dalam kelompok dimana satu kelompok terdiri dari 4 orang, sesuai dengan refleksi dari siklus 1 maka siswa dalam kelompok siklus 2 terdiri dari siswa yang aktif dan kurang aktif pada siklus 1 . Setelah siswa menempatkan diri pada kelompok masing-masing maka terlebih dahulu guru menjelaskan tentang bentuk proyek yang akan dikerjakan oleh siswa.

Guru memberikan tugas kepada masing-masing kelompok untuk merancang proyek yang akan dibuat, selama proses perancangan proyek berlangsung guru memiliki peran sebagai pendamping serta memonitoring dan melayani konsultasi pembuatan rancangan proyek dari kelompok.

Guru memeriksa hasil rancangan tiap-tiap kelompok dan memberikan masukan bagi rancangan yang belum mencakup unsur dari materi yang telah diajarkan. Kelompok yang telah mencakup unsur dari materi yang telah diajarkan maka guru memberikan persetujuan kepada kelompok untuk bisa melanjutkan ke proses pembuatan proyek. Sebelum dilanjutkan ke proses proyek maka perencanaan dari semua kelompok dipresentasikan dan didiskusikan bersama. Saran dan masukan selam diskusi dijadikan acuan dalam perbaikan perencanaan proyek. Selanjutnya guru menutup pembelajaran dan diakhiri salam.

\section{2) Pertemuan Kedua}

Pertemuan kedua sama halnya dengan tindakan yang dilakukan pada pertemuan pertama, guru mengkondisikan kelas dengan mengecek kehadiran siswa. Pembelajaran dilanjutkan dengan guru memberikan motivasi kepada siswa dengan menjelaskan aplikasi Instalasi motor listrik di dunia industri dan dunia usaha.

Kelompok melapor ke teknisi agar dapat mempersiapkan peralatan dan bahan yang dibutuhkan untuk pembuatan proyek, setelah alat dan bahan dipersiapkan maka kelompok memulai proses pembuatan sesuai dengan rancangan yang telah disetujui oleh guru.

Siswa melaksanakan proses pembuatan proyek mulai dari mempersiapkan alat dan bahan, selama proses pembuatan proyek guru bertugas mendampingi dan membimbing siswa dalam melaksanakan praktik, serta menilai dan mengamati setiap langkah kerja yang dilakukan oleh setiap kelompok. Setelah selesai melaksanakan pratikum di pertemuan kedua ini maka siswa diinstruksikan untuk mengembalikan peralatan dan membersihkan workshop.

Sebelum proses praktikum dibubarkan siswa dikumpulkan untuk menyampaikan kendala yang dihadapi selama proses pratikum sehingga ini menjadi bahan masukan untuk melakukan praktikum di pertemuan berikutnya. Selanjutnya guru menutup pembelajaran dan diakhiri salam.

\section{c. Observasi}

Observer selama penelitian melakukan pengamatan terhadap proses pembuatan proyek. Observer mengamati setiap kegiatan yang dilakukan oleh siswa untuk pengambilan data tentang proses pembuatan proyek. Pengamatan yang dilakukan pada siklus 2 tidak terlalu berbeda 
dengan yang dilakukan pada siklus 1 . Observer mengamati setiap kegiatan yang dilakukan kelompok dalam pembuatan proyek dan memberi tanda ceklist pada lembaran proyek sesuai dengan indikator yang ada pada lembaran proyek. Observer juga ikut dalam melakukan pengawasan terhadap kegiatan yang dilakukan siswa pada siklus 2.

Setelah dilakukan penilaian maka diperoleh bahwa kemampuan psikomotorik siswa didapatkan melalui hasil penilaian rubrik penilaian kinerja, yang disi selama siswa melakukan kegiatan pembelajaran praktikum, penilaian dilakukan oleh guru dan dosen dalam pelaksanaan proses pembelajaran. hasil rubrik penilaian kinerja disajikan pada tabel 4.2 berikut ini

Tabel 4.2. Hasil Belajar kemampuan Psikomotorik Siklus 2

\begin{tabular}{|c|c|c|c|}
\hline No & Responden & $\begin{array}{c}\text { Nilai Total } \\
(\%)\end{array}$ & Kriteria \\
\hline 1 & A & 90 & Sangat Baik \\
\hline 2 & B & 79 & Baik \\
\hline 3 & C & 83 & Sangat Baik \\
\hline 4 & D & 75 & Baik \\
\hline 5 & E & 70 & Baik \\
\hline 6 & F & 85 & Sangat Baik \\
\hline 7 & G & 78 & Baik \\
\hline 8 & H & 70 & Baik \\
\hline 9 & I & 90 & Sangat Baik \\
\hline 10 & J & 89 & Sangat Baik \\
\hline 11 & K & 68 & Baik \\
\hline 12 & L & 92 & Sangat Baik \\
\hline 13 & M & 70 & Baik \\
\hline 14 & N & 65 & Baik \\
\hline 15 & O & 89 & Sangat Baik \\
\hline 16 & P & 85 & Sangat Baik \\
\hline Rata-Rata & 79,8 & Baik \\
\hline
\end{tabular}

Dari tabel diatas diketahui bahwa kemampuan psikomotorik siswa mengalami peningkatan yang signifikan, dimana masing-masing siswa secara keleluruhan mengalami peningkatan dengan presentase peningkatan yang berbeda-beda jika dibandingkan dengan hasil pembelajarna sebelumnya, jumlah siswa yang memperoleh nilai pada taraf maksimal juga mengalami peningkatan yakni sebanyak 8 orang ( $50 \%$ ) dari 16 siswa. Selain itu, tidak ada lagi siswa yang memperoleh nilai kemapuan psikomotorik yang berada pada taraf cukup, semua berda pada taraf baik hingga sangat baik (seperti terlihat pada gambar 4.2). Hal ini mengindikasikan bahwa dengan beberapa perubahan dan perbaikan dari penerapan model pembelajaran project based learning ini hasil belajar siswa semakin meningkat.

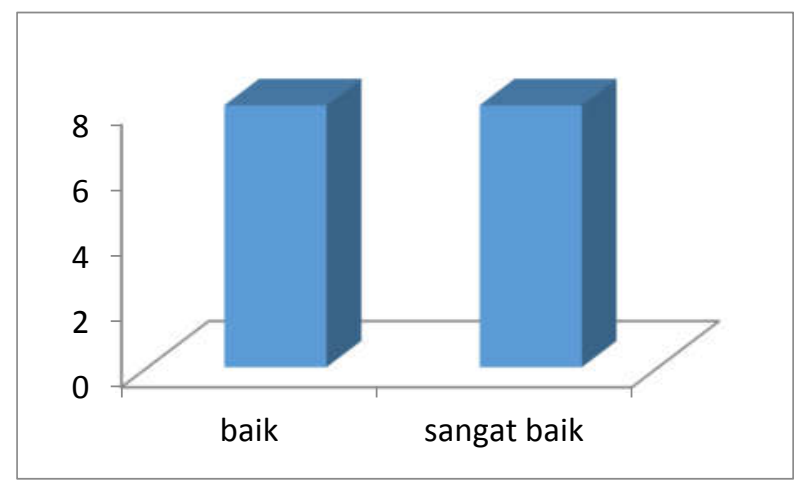

Gambar 4.2 Grafik Hasil Belajar Psikomotorik Siswa pada Siklus 2

\section{d. Refleksi}

Kegiatan pembelajaran siklus 2 dilakukan setelah mengalami beberapa perbaikan dan penyempurnaan dari penerapan model pembelajaran project based learning berdasarkan temuan kelemahan pada penerapan yang sebelumnya. Hasil belajar psikomotor siswa selama tindakan dilaksanakan pengamatan sehingga diperoleh hal-hal berikut:

1) Pembelajaran yang telah dilaksanakan sudah mencerminkan penerapan model pembelajaran project based learning karena secara umum proses pembelajaran berjalan sesuai dengan rencana yang telah disusun.

2) Hasil belajar siswa pada ranah psikomotor juga mengalami peningkatan yang signifikan, dimana penyebaran peningkatan hasil belajar telah merata untuk masing-masing individu, 8 orang siswa memeperoleh nilai pada taraf maskimal yaitu sangat baik, dan 8 orang siswa lainnya memperoleh nilai pada kategori baik, pada siklus dua ini tidak ada lagi siswa yang memperoleh nilai cukup.

Mengacu kepada hasil yang didapatkan pada siklus dua ini maka dapat diketahui bahwa tujuan dari pelaksanaan penelitian ini telah tercapai, maka degan demikian penelitian tindakan kelas ini diakhiri pada siklus dua ini untuk selanjutnya dilaksanakan pembahasan dan analisis dari data yang didapatkan selama pelaksanaan penelitian. 


\section{KESIMPULAN}

Berdasarkan penelitian yang telah dilakukan mengenai penerapan model pembelajaran Project Based Learning, maka dapat disimpulkan bahwa Penerapan model pembelajaran Project Based Learning dapat meningkatkan hasil belajar siswa pada ranah psikomorik, dimana berdasarkan hasil pengamatan dengan menggunakan rubrik penilaian kinerja pada siklus 1 telah terjadi peningkatan hasil belajar siswa jika dibandingkan dengan hasil belajar dengan model pembelajaran yang sebelumnya, kemudian peningkatan hasil belajar siswa semakin membaik pada siklus 2 setelah dilakukan beberapa penyempurnaan dalam pelaksanaanya, siswa tanpak lebih semangat dan berperan aktif dalam proses pembelajaran, guru berperan sebagai fasilitator dalam pelaksanaan proses pembelajaran.

Berdasarkan hasil penelitian yang telah diungkapkan di atas dapat diberikan saran sebagai berikut. Pertama, Guru sebagai pendidik sebaiknya dalam proses pembelajaran memilih model pembelajaran yang tepat dan sesuai dengan karakteristik siswa dan karakteristik materi pembelajaran sehingga proses pembelajarn dapat berlangsung optimal terutama dalam mencapai tujuan pembelajaran. Salah satu dari model pembelajaran terseebut adalah model pembelajaran Project Based Learning.

Kedua, Siswa, agar dapat lebih berperan secara aktif dalam proses pembelajaran, karena pradigama pembelajaran yang terpusat kepada guru sudah berubah kepada proses pembelajaran yang terpusat kepada siswa, dimana siswa dituntut lebih aktif dalam melaksanakan pembelajaran sehingga proses pembelajaran dapat berlangsung secara optimal.

\section{Daftar Pustaka}

[1] Anas Zulfikri (2004). Menciptakan Keunggulan Layanan Terhadap Siswa Dalam Upaya Membangun Karakter Per Individu Siswa (Modul Workshop Kurikulum), Jakarta: Puskur Balitbang Dediknas.

[2] Depdiknas (2004). Pedoman Penyusunan Usulan Penelitian Tindakan Kelas. Jakarta : Ditjen Dikti.

[3] Depdiknas (2008). Pengembangan dan Penerapan Model Pembelajaran Berbasis Kompetensi. Jakarta : Ditjen Managemen Dikdasmen, Dit PSMK.

[4] Depdiknas (2008). Pengelolaan Pembelajaran Berbasis Kompetensi. Jakarta: Ditjen Managemen Dikdasmen, Dit PSMK.
[5] Kemdikbud (2012). Bahan Ajar Diklat Asistensi dan Bimbingan Penelitian Tindakan Kelas. Medan : P4TK BBL.

[6] Mohammad Asrori (2008). Penelitian Tindakan Kelas. Bandung : Wacana Prima.

[7] Nasution (1992). Berbagai Pendekatan Dalam Proses Belajar dan Mengajar. Jakarta: Bina Aksara.

[8] Woodworth dan Marquis (1951). Psychology. New York : Henry Hold Company.

[9] Trianto. 2009. Mendesain Model Pembelajaran Inovatif-Progresif. Jakarta: kencana Prenada media group

[10] Rusman. 2010. Model-model Pembelajaran Mengembangkan Profesionalisme Guru. Jakarta: PT Rajagrafindo Persada.

[11]Ridwan A. Sani \& Sudiran (2012). Meningkatkan Profesionalisme Guru Melalui Penelitian Tindakan Kelas. Medan : Cita Pustaka.

[12] Ahmad Sudrajat. 2008. Pengembangan Perangkat Penilaian Psikomotor. Online. http://akhmadsudrajat.files.wordpress.com/2008 /08/penilaian-psikomotor.pdf

[13]Depdiknas. 2008. Pengembangan Perangkat Penilaian Psikomotor. Jakarta : Gramedia.

[14]Suharsimi Arikunto, 2006. Prosedur Penelitian.Jakarta: PT RINEKA CIPTA

\section{Biodata Penulis}

Fivia Eliza, M.Pd., Lahir Di Seleman (Kerinci), 07 Agustus 1985. Tahun 2009 Memperoleh Gelar Magister Pendidikan Di Jurusan Teknologi Pendidikan Program Pascasarjana UNP Dengan Konsentrasi Pendidikan Kejuruan. Staf Pengajar Di Jurusan Teknik Elektro FT UNP Sejak Tahun 2009-Sekarang.

Suriyadi, adalah salah satu tenaga pengajar di Sekolah Menengah Kejuruan Negeri 5 Padang, Sumatera Barat.

Doni Tri Putra Yanto, lahir di Cupak, 16 April 1993. Sarjana Pendidikan Teknik Elektro di Jurusan Teknik Elektro, Fakultas Teknik UNP tahun 2014. Tahun 2016 memperoleh gelar Magister Pendidikan Teknologi dan Kejuruan konsentrasi Teknik Elektro Program Pascasarjana FT UNP. Staf pengajar di Jurusan Teknik Elektro FT-UNP Padang tahun 2017-sekarang. 